\title{
Producing Local Neoliberalism in a Leftist Regime: Neoliberal Governmentality and Populist Transition in West Bengal, India
}

\author{
Ritanjan Das \\ University of Portsmouth, Faculty of Business and Law, Portsmouth, UK
}

\begin{abstract}
This paper presents a theoretical reassessment of a much debated chapter in India's economic liberalisation - the case of West Bengal, a state ruled by the pro-labour Left Front coalition, led by the Communist Party of India-Marxist (CPIM) from 1997 to 2011. The onset of neoliberalism in India had naturally created a serious political dilemma for the CPIM, but it eventually transitioned to a private-industrialisation agenda, thus prompting serious questions about its ideological deviation from a Leftist path. While the political-economy of the CPIM/Left Front and its
\end{abstract}


industrial fortunes have been under extensively scrutinised, this study introduces a rather different theoretical perspective on the story. Going back to the initial period of the policy transition (c.1994), it uses the analytical categories of local neoliberalisms and populist transition to show how the state of affairs in West Bengal under the CPIM was demonstrative of a particular variant of interventionist neoliberal governmentality, characterised by a gradual intensification of pro-market impulses in both action and discourse. Furthermore, the study also contextualises West Bengal within wider political economic trends, arguing that pro-market transitions by populist regimes tend to be characterised by a series of mobile calculative techniques of governing, embedded in local historical and geographical specificities and localised relationships.

Keywords: West Bengal, CPIM, Left Front, local neoliberalism, neoliberal governmentality, populist transition 


\section{Introduction}

The ubiquitousness of the grand project of neoliberalism has often spurred a degree of perplexity, especially in its rapid advent from a stark utopian intellectual movement to a new orthodoxy within a few decades. However, in spite of the overbearing causal agency ascribed to neoliberalism by advocates and critics alike, it remains a project to realise the all-encompassing conditions of economic globalisation (Tickell and Peck, 2003), the political character of which needs to be closely studied. This is not a recent observation. Peter Dicken $(1997,1998)$, for example, has long argued against the highly abstract conceptualisation of globalisation, maintaining that its processes are initiated and mediated by economic and political actors. In fact many economic geographers have strongly opposed the 'flat-earth' conceptions of neoliberal globalisation, asserting that neither does it produce unitary outcomes, nor do they erase local/national differences (Yeung and Peck, 2003). Neoliberalism, as Tickell and Peck point out, 'produces its own geography, the resultant unevenness reflecting... an array of politically mediated forms of integration into a complex and changing global economic system' (2003:164). It is therefore important to understand the variable ways in which different forms of local neoliberalisms are developed through such uneven socioeconomic processes, embedded within wider networks and structures of the Washington Consensus style-neoliberalism. Neoliberal politics, albeit appealing to universal concepts such as market efficiency, is essentially a form of hybrid politics, reflecting the balance of local political forces and institutional arrangements (Peck and Tickell, 2002). A plethora of literature has developed studying such variegated and localised forms of arrangements, and in one of the earlier papers of its kind, Moore (1997) conceptualised the politics of liberal economic reform as a rapidly expanding field, the economic transformation of the developing world in the last few decades being widely studied and debatedi

Sharpening the analytical focus on different forms of local neoliberalisms, let us turn to the phenomenon of transition. Remaining attentive to the localised variants, it can be argued that 
transition from one form of neoliberalism (or pre-neoliberal/dirigiste economic rationalities) to another is hardly a straightforward one, being shaped by a range of nationally/locally specific and qualitatively differentiated forms of political-economic and institutional arrangements (Tickell and Peck, 2003, Amin, 1997, Dicken et al, 1997). Transition outcomes, therefore, are hardly homogeneous, 'but a continuous process of uneven development within which neoliberal impulses are intensifying', the task being to trace this unevenness over time and space (Tickell and Peck, 2003:165). Furthermore, within divergent forms of transition initiatives, probably the most intriguing forms are those engineered by Leftist democratic parties/alliances (Moore, 1997). The adoption of neoliberal reforms pose a particular challenge for such regimes, as it induces a withdrawal from traditional Leftist policy commitments, thereby putting 'severe strains on the unity and coherence of populist parties' (ibid.:1009). Similar arguments have also been put forward recently: Steur and Das (2009) observe that managing transition is particularly challenging for states that explicitly legitimise their rule in terms of communist ideals, and whose ideological pillars include pro-poor redistributive programmes. There are many such cases in point: from the USSR/Eastern European nations to several Latin American (Brazil, Mexico), and Asian (China, Vietnam) countries. This paper is an attempt to bring the dynamics of one such case - in the Indian state $^{\mathrm{ii}}$ of West Bengal - to the forefront, and albeit widely studied, the dual perspectives of local neoliberalism and populist transition provide a rather novel insight to the case, and therefore will be the mainstay of the discussion.

\subsection{The Case of West Bengal}

This paper explores a localised form of neoliberal transition - characterised by a distinct set of ideological contradictions - brought about by the main Leftist-democratic party of India, the Communist Party of India-Marxist (CPIM). The CPIM spearheaded a 'Left Front' coalition iii government in West Bengal for over three decades (1977-2011): one of the world's longest, 
democratic Leftist governments, and a rare instance of political stability amidst a chaotic Indian democracy, decisively winning seven consecutive elections. The longevity of the CPIM/Left Front regime has been the subject of countess debates (Sarkar, 2006), and its (substantial) development record closely scrutinised. It initiated large-scale land reforms, was the first among Indian state governments to seriously pursue democratic decentralisation via the panchayati-raj (a system of local governance through village councils), and gained unprecedented popularity as a 'government for the poor' (Bhattacharyya, 2016).

The CPIM/Left Front closely follows Moore's (1997) characterisation of 'populist' regimes, upholding the betterment of the poor as its primary motivation. It initially operated with an almost militant attitude towards private industrialisation (Dasgupta, 1998) - focusing on agriculture, smallmedium units and the public sector instead - and in the post-1991 era of Indian economic liberalisation, remained a staunch critic of the reforms initiated by the central government. And yet, throughout the 1990s, while keeping its opposition alive at a national level, the regime gradually adopted a pro-market transition in its approach towards industrialisation in West Bengal. While the direction and pace of change were gradual, it picked up post-2000 as the government started actively promoting private industrialisation. But things took a rather spectacular turn for the worse post-2006, as the government tried to forcibly acquire fertile farmland for private entrepreneurial ventures in two small hamlets of Singur and Nandigram, resorting to indiscriminate violence by the police and armed party cadres (hundreds were injured, and even 14 people were killed in Nandigram) (Nielsen, 2018; Sarkar \& Chowdhury 2009). Consequentially, the regime steadily lost support, eventually relinquishing office in 2011.

Such a dramatic turn of events - a pro-poor Left government almost imploding after forceful land acquisition at the apparent behest of multinational corporations - naturally evoked sharp reactions. However, these predominantly focused on whether the CPIM/Left Front had deviated from a 'Leftist' path, 'succumbed to the capitalist paradigm of development' (Gohain, 2011:80), and 
'abandoned the project of 'transcending capitalism'... [being] no different from any standard bourgeois party' (Shankar, 2011:76). Both the media and a section of academia frequently used phrases like 'loss of class character', 'ideological degeneration' and 'leadership arrogance' to advance a compelling thesis of moral/ideological bankruptcy of the regime, thus reinforcing the observation of a rather stark shift in its Leftist orientation (see Bandopadhyay, 2006; Banerjee, 2008; Bose, 2013).

Now, although instructive, such characterisations suffer from one major shortcoming. Most observations (correctly) point out the CPIM/Left Front's 'confounded approach to neoliberal globalisation' as demonstrative of its degeneration, but rarely interrogate the nature of this 'confounded approach', subsuming it within the wider narrative of 'dilution of Leftism' instead. However, as this paper argues, what remained largely unnoticed was the production of a rather unique form of local neoliberalism in West Bengal, with a multitude of contradictory forces giving it a distinct shape. The regime went through some significant policy and ideological churnings following the USSR disintegration and the onset of liberalisation in India, and its gradual transition to a pro-market stance needs to be seen in that context. However, neither has there been much discussion on the reasons that prompted such a shift, nor an interrogation of how the regime reworked its ideological rationale to justify the same, both being crucial components of the gradual intensification of neoliberal impulses in the state.

Therefore, although there has been a renewed attention on West Bengal following the spectacular collapse of the CPIM in $2011^{\text {iv }}$ and the continuous nationwide disintegration of Left forces (Bhattacharyya, 2016; Das, 2018), there remains a scope to retell this story, particularly in terms of its populist challenges and resolution. By doing so, the story can be situated within broader arcs of political transformations induced by the neoliberal era, and yet the transformative forces being distinct enough to produce a unique variant of local neoliberalism. In essence, this paper tries to answer the following question: how was a distinct form of local neoliberalism produced by the CPIM/Left 
Front in West Bengal, in which ideologies of neoliberalism were themselves produced or reproduced through institutional forms and political negotiations, in spite of being often contrary to the character of a populist regime? Methodologically, the paper draws from a broader (doctoral) research involving a six months' ethnography in Calcutta (the state capital) and rural West Bengal, alongside a significant amount of archival research, examining newspaper articles, political party literature, and government reports. The story presented below emerges out of an extensive set of archival material and interviews conducted with bureaucrats, politicians, and journalists, demonstrating the complex processes behind the production of this particular form of local neoliberalism.

The structure of the paper is as follows: the next section develops the theoretical framework. The following section reconceptualises the nature of populist transition in West Bengal by looking back at (a) the historical process of the transition itself, (b) the resultant ideological ambiguities, and (c) the production of a neoliberal governmentality via a recalibration of the regime's legitimising discourses. The concluding section places the West Bengal variant of local neoliberalism in a broader theoretical context and similar developments elsewhere.

\section{Neoliberal Governmentality, Local Neoliberalisms and Populist Transitions}

Having laid out the broad contours of the story, let us now elaborate the theoretical elements. The core theoretical strand of this work is the production of a local neoliberalism, its specific form being a populist transition, the post-1991 Indian neoliberal era giving it a wider context. Let's examine these in turn.

The $21^{\text {st }}$ century variant of neoliberalism has become a commonsense of the times. As Peck and Tickell (2002) point out, confronted with a hegemonic order, the new challenges are about understanding the ways neoliberalism is conceived, imposed and reproduced at national or local 
levels. The role of nation-states in such processes is critical, and although overgeneralised accounts often tend to be insufficiently sensitive to regional/localised variabilities, international or supranational transactions often reinforce the structure and importance of nation-states (Cerny, 1990; Pooley, 1991). Developments in political theory have long asserted the qualitative role of the state, going back to Karl Polanyi's The Great Transformation (1944). More recently, Offe (1984), Block (1994), O’Neill $(1996,1997)$, have emphasised the centrality of nation-states in producing the means of overcoming the contradictions of capitalist production, the organisation of collective activities, and the pursuit of common goals, while relying on capitalism for financial viability.

The political project of neoliberalism is a complex and multifaceted process, for it involves the development of new forms of statecraft, some concerned with market-building initiatives, while some with managing its consequences and contradictions (Tickell and Peck, 2002; Brenner and Theodore, 2002a, 2002b; Larner, 2000). Ong (2006) provides a useful conceptualisation of this process, labelling it as small $n$ neoliberalism: a new mode of political optimisation, reconfiguring relationships between governing and the governed, power and knowledge, sovereignty and territoriality. A new mode of 'governmentality', it's a historical process that unevenly articulates situated political constellations, particularly in emerging economies where neoliberalism is not the general or traditional characteristic of governing technologies. The advent of neoliberalism therefore assumes an interventionist mode. Ong characterises this interventionist neoliberal governmentality as an infiltration of market-driven truths and calculations into the domain of politics, informing action by regimes according to market principles. The most crucial element in this form of governmentality is the conceptualisation of neoliberalisation as an exception, an extraordinary departure in policy that can be deployed to include as well as exclude. In other words, the interventionist aspect of neoliberal governmentality takes shape as an exceptional articulation of sovereign rules and regimes of citizenship, choosing to include or exclude 'selected populations and spaces as targets of "calculative choices and value-orientation" associated with neoliberal 
reform' (ibid.:5). Ong ethnographically demonstrates the variegated forms of such interventions in liberal democracies as well as postcolonial, authoritarian and post-Socialist situations in East and Southeast Asia, urging further explorations of the interplay between technologies of governing and disciplining, of inclusion and exclusion.

Tickell and Peck (2003) gives this intervention a more processual context, arguing that neoliberal governmentality needs to be understood as a process and not an end-state. The focus should particularly be on change, on shifts in systems and logic, on dominant patterns of restructuring, while being sensitive to its contingent nature on socio-political contexts. Pursuing interventionist neoliberal governmentality is not about the superiority of markets, as it's often necessary for state agencies to promote its exceptional character, deploying 'state power and public authority in pursuit of these goals, underlining the reality that 'markets' are not naturally occurring phenomenon...they have to be made, steered and policed' (ibid.:167). Therefore, the programmatic implementation of neoliberal projects, from the ground up, is invariably more prosaic, contradictory, and has little to do with laissez-faire deregulation. It is associated with extensive deconstruction and reconstruction of institutions, only in the name of or in the image of 'markets'. The 'project' is invariably variegated, localised, and pervasive. And it is this diverse political exercise of institutional cluttering is what constitutes local neoliberalisms, legitimised by and embedded within wider networks and structures of neoliberalism, but in reality mutated into a number of historically and geographically distinct forms.

The task of mapping the historical geography of local neoliberalisms remains limited at best. Tickell and Peck (ibid.) however have schematised the political shifts producing local neoliberalisms from 'proto-neoliberalism', through 'roll-back neoliberalism', to 'roll-out neoliberalism':

- Proto-neoliberalism: the economic slowdown of the 1970s challenged the Keynesian postWar consensus as economic growth faltered, tax revenues fell, and spending spiralled. In 
response, the neoliberal state project emerged as an experimental shock-therapeutic approach for certain developing economies.

- Roll-back neoliberalism: emerging from the experimental 1970s, neoliberalism evolved into a dominant state strategy in the 1980 s, guided by a clear set of programmatic principles emphasising low taxes and bureaucratic roll-backs. Some of the key principles included minimising government sizes, facilitating private competition, wealth redistribution, etc. This was also a phase of phenomenal success of neoliberalism, leading to a normalisation of neoliberal modes of regulation for economic policy decisions.

- Roll-out neoliberalism: since the 1990s, the central tenets of the neoliberal project have been absorbed into a hegemonic ideology, infusing mainstream political discourses across the world. While its reach and purchase remain uneven, the dominant form of neoliberalism has transformed from the crude roll-back forms into much deeper forms of neoliberal state-building.

Acknowledging that this schematisation is more representative of the global North, Peck and Tickell (2002) emphasise the need for more attention in mapping the production of various localised neoliberal states in the global South. Now, this process is particularly intriguing in case of populist transitions, as the nature of localised changes facilitating neoliberal governmentality is nowhere as contested as populist parties undertaking economic reforms, almost inevitably cutting public expenditures, subsidies, etc., thus challenging the loyalty of party cadres and supporters. More crucially, upholding the credibility of economic liberalisation generally requires governments to openly reject traditional leftist policy commitments that are ideologically as well as materially important to populist parties. How under these circumstances do they manage to survive and ensure legitimacy? 
There are several theoretical strands that explore such cases, ranging from collective action models (Haggard and Kauffman, 1991), parties/interest groups coalition (Chibber, 2003; Bret, 2008), government-union interactions (Murrillo, 2001), to political management of transition (Haggard and Webb, 1994; Burger and Levitsky, 2003). One of the most influential is Grindle and Thoms's (1991) formulation based on their study in Sri Lanka, that party and government leaderships often have considerable autonomy to shape both politics and policy, especially when they can present the situation as one of crisis requiring urgent, decisive action. Gibson's (1997) study of the Peronist Party (Argentina) and the PRI (Mexico) on the other hand proposes the idea that these parties comprise two distinct components: a rural-based 'peripheral' component, and a modern sector based 'metropolitan' component. The former mainly delivers electoral support, the latter provides organisational and ideological resources. Gibson argues that in Argentina and Mexico the shift from populism to neoliberalism has been achieved because party leaderships have been able to reconstitute the metropolitan components from pro-liberal forces, while the peripheral component has stayed largely intact and provided electoral weight.

Before turning to a closer examination of West Bengal in light of these observations, a few pointers should be provided about Indian exceptionalism within the wider gamut of neoliberal transformations. The transition of the Indian economy from a dirigiste era (state dominated/inward looking) to economic liberalisation has been a recurring topic in academic debates ever since India embraced an era of concerted economic reform in 1991. However, much of the discussion has been dominated by an insistent preference for 'markets' over 'states', both in terms of the mainsprings of reform and of its social and spatial consequences (Corbridge, Harriss and Jeffrey, 2013). Jenkins (1999) and Sinha (2004, 2005), however, does much to underline the sub-national variations, both arguing that it is in the 'local/micro-level' accounts that the political logic of reforms can be found. Secondly, the argument that nation-states tend to pursue national rather than international interests even while pursuing liberalisation can be taken one step forward for the 
Indian states. In post-1991 India, states became agents championing regional interests, inaugurating new political alliances and accommodating initiators in the process of incremental reforms. As a result, inter-state economic performances diverged significantly, some states firmly placed on the reform bandwagon (such as Maharashtra, Gujarat, Tamil Nadu), while some continuously lagging (West Bengal, Bihar, etc.). Such variations have led to persisting concerns about the aggravation of financial disparities and increasing economic polarisation among states (Sáez, 2002), and how a regional Left regime would adjust in such a situation has been a perplexing question for decades (Corbridge, Harriss and Jeffrey, 2013). A theoretical reassessment of West Bengal therefore has the potential to add to the pluralist views of Indian politics that inform some of these arguments.

\section{Reconceptualising the Populist Transition in West Bengal}

How does one characterise the populist transition in West Bengal? There were of course a wide range of local political-economic conditions (see Das and Mahmood, 2015). But keeping the theoretical schema developed earlier in sight, the first point to acknowledge, one that sets West Bengal (and Indian states in general) apart, is that this is a case of a regional government within a larger federal jurisdiction with a limited decision making space (thus putting it in direct contrast to Grindle and Thomas (1991) and other conceptual frameworks, most of which look at nation-states as a whole). Unlike cases outside India, the transition in West Bengal was not an overarching economic transformation, but was evident mostly in the government adopting certain subtle shifts in favour of private-capital led industrial development.

There is a plethora of literature on the political history of the CPIM/Left Front (Bhattacharyya, 2016), on its governance and development records (Kohli, 1987; Nossiter, 1988), agricultural productivity (Rogaly, Harriss-White et al, 1995), and the formation of a new hegemonic class of 
political beneficiaries (Mallick, 1993; Rogaly, 1994; Roy, 2004; Ruud, 1999) or the party-society (Bhattacharyya, 2009, 2010, 2016). While industrial development in West Bengal has also been discussed extensively (Dasgupta, 1998; Pederson, 2001; Sarkar, 2007; Chakravarty and Bose, 2013), the bulk of this literature focuses either on the institutional ineffectiveness behind the regime's industrialisation initiatives, or criticises its high-handedness in matters of land acquisition. There are also debates on the regime's subsequent political-ideological degeneration, leadership struggles, and eventual capitulation from power (Bardhan, Mitra et al, 2012; Bose, 2013; Chatterjee and Basu, 2009). But in this wide ranging literature, what often remains underexplored is how the state of affairs were also demonstrative of the challenges of a populist transition, and how the associated political negotiations produced a unique form of local neoliberalism. Unlike elsewhere, here there was no fiscal/trade policy regulation or large scale institutional overhaul, but only a transition in the regime's attitude towards private capital and some institutional rearrangements. Both the challenge and uniqueness of this transition instead is to be found in the transformations in political ideas, and the legitimisation that the regime sought from such transformations, both being key features of the local neoliberalism produced in the state (thus also standing apart from Gibson's (1997) characterisation).

\subsection{Industrial Transition in West Bengal: Proto, Roll-back and Roll-out Phases}

Unlike the global North, the processual nature of transition (proto-rollback-rollout) in West Bengal (and elsewhere in India) was hardly linear. However, there are a few commonalities. The protoneoliberalism phase is usually characterised by an emergence of a crisis that establishes the conditions for a transition, and developing an argument that necessitates it, arguing there is no alternative (TINA). The roll-back phase sees an effective normalisation of neoliberal modes of regulation, a taken-for-granted context for economic decision making, eventually consolidating as 
a depoliticised technocratic approach towards policy formulation in the roll-out phase. West Bengal was no exception to this.

Upon assuming power in 1977, the Left Front issued a Statement on Industrial Policy (GoWB, 1978), expectedly reasserting its populist character. First, the policy repeatedly expressed a militant attitude towards big corporations, accusing them of 'utilizing the profits realised from West Bengal...either for supporting the lavish style of living of the owners...for setting up industries elsewhere, or for remitting funds abroad', and hence there was 'no question of allowing new multinationals to come in' (ibid.:103-105). Second, reviving the once-flourishing industrial units of the state was hardly prioritised, arguing that a revival would help 'the monopoly houses and the multinational companies...This would be wholly against the principles of the Left Front' (ibid). Third, there was a strong emphasis on continuous attempts to influence central government policy, pursuing a 'major modification in the allocation of powers between the Centre and the States in such matters as industrial licensing' in favour of the state (ibid.:107).

Following such an approach - commonly referred to as the Left alternative (alongside land reforms, democratic decentralisation via the panchayats, and a larger objective of self-reliance) - the post1978 industrialisation scenario in West Bengal seemed rather bleak. While agrarian reforms and decentralisation measures did improve rural income (Chakravarty and Bose, 2013), the impact on the state's overall economy was limited. Between 1980 and 1990, per-capita SDP growth in West Bengal was extremely sluggish, registering one of the lowest rates among the fourteen non-special category states (Table 1), and a declining industrial sector (Tables 2 and 3).

\footnotetext{
$<$ insert Table 1>

<insert Table 2>

$<$ insert Table 3>
} 
Irrespective of such stagnating conditions, the post-1991 era of Indian liberalisation was a complete antithesis to Left ideology. The CPIM mounted a well-constructed critique of the new economic policies (NEP), the allegations ranging from a moral betrayal of the socialist dream (which the Nehruvian principles stood for as well) to emotional outbursts accusing the Congress of selling out the nation to foreigners (Das, 2018). And yet, in spite of politically denouncing the NEP in public at every opportunity, as the Left Front leader the CPIM seemed to accept that some positives indeed came out of it, particularly by abolishing the licencing system of industrial allocation, which it had always accused of being discriminatory. The 1992-93 West Bengal Economic Review even acknowledged that freeing the industrial sector from the compulsion to seek licenses has indeed increased investment proposals for the state (Pederson, 2001)

The watershed moment of this story came in September 1994, when the Left Front published a renewed Policy Statement on Industrial Development, deviating significantly from the rhetoric of the 1978 Statement. It read:

The State Government welcomes foreign technology and investments, as may be appropriate, or mutually advantageous... [] t recognises the importance and key role of the Private Sector in providing accelerated growth (GoWB, 1994:7-8).

Consider the following points with respect to the features of the 1978 Statement discussed earlier:

1. The sceptical and almost militant attitude towards multinationals was completely reversed, and the state was promoted as an attractive destination for private capital:

Apart from...large Indian Industrial Houses...a number of Multinational Corporations (MNCs) have long been successfully operating in the State.... A welcome development is that a good number of Non-Resident Indians (NRIs), MNCs directly or through foreign Governments and Indian Industrial Houses have, in the recent past, shown special interest in coming to West Bengal (ibid). 
The Statement also declared that all sectors - private, joint and public - would be treated as effective instruments for mobilising necessary resources and expertise in important areas of economic activity.

2. Contrary to the earlier claims that the revival of sick industries would strengthen the grip of monopolists, the government now promised that all such units in the private sector would be 'reopened and rehabilitated appropriately at the earliest' (ibid.:14).

3. Finally, several policy instruments were introduced to speed up industrialisation, ${ }^{\mathrm{v}}$ indicating gradual changes in government attitude. These included (a) a proposal to strengthen WBIDC (West Bengal Industrial Development Corporation); (b) expedited decisions and clearances for large projects; and (c) setting up various committees to ensure rapid decisions regarding land, employment and other related matters.

The 1994 Statement is the cornerstone upon which the subsequent industrialisation drive in West Bengal was based. The government also initiated several politically risky shifts, such as allowing the private sector to enter the infrastructure, health, and even education sectors. The most important institutional change was the reorganisation of the WBIDC and appointment of Somenath Chatterjee ${ }^{\mathrm{vi}}$ - a senior and widely respected CPIM leader - as its Chairman, who (along with Jyoti Basu, Chief Minister of West Bengal, 1977-2000) intensified the promotion of West Bengal as an attractive investment destination through many foreign tours and visits. Despite the party having long dismissed mainstream media as 'bourgeois', the government started signalling its commitment to the reform agenda by drastically increasing the volume of interviews and press statements. In most of his interviews, Chatterjee argued explicitly that the government needs to undertake 'large' and 'stronger' reforms: 
Unfortunately there is still the feeling among a section of the industry: Why should we go to a communist-led state? This should prompt us to be more aggressive in projecting West Bengal. We must attract private capital. I don't see any alternative (quoted in Sinha, 2004).

In retrospect, the 1994 Statement marks the first moment of transition in the political-economic history of West Bengal. But as characteristic of the proto-neoliberalism phase, the persistently declining economic conditions in the state throughout the 1980s necessitated the transition, allowing the regime to frame the TINA argument (evident in Chatterjee's statement above). The subsequent developments (the institutional initiatives, media outreach etc.) indicate a gradual normalisation and consolidation of the new regulatory modes, reflective of the roll-back phase. At the same time, a novel attempt was being made to de-link government from politics. The 1978 Statement was an effort to link the struggle for production with the on-going class struggle of the Left parties. The 1994 Statement was, on the contrary, largely apolitical. The focus was on income and employment generation via industrial revival and growth rather than 'revolution' or 'class struggle' (reflective of the technocratic shift of the roll-out phase, as companies such as Price Waterhouse were brought in for advisory purposes). But in this process, the CPIM was confronted with an additional policychange dilemma not faced by any other centrist or right-wing party in India: how to 'modify its ideological agenda toward public sector-led industrialization and redistributive economic policy strategies without losing its core base of political support' (Sinha, 2004:80). These ideological conundrums are the salient features of the local neoliberalism that took shape in West Bengal.

\subsection{Ideological Conundrums of a Populist Transition}

In trying to modify its ideological agenda, two specific ambiguities emerged within the CPIM in this period. First, its role in promoting a revolutionary alternative versus long-term governmental duties, and second, the implications of the USSR collapse. Let's examine these in turn. 
The ideological discourse of the CPIM assumed that before heralding a people's democratic revolution (PDR), the party might have to occupy power for a transitional period (CPIM Party Programme, 1964). However, in spite of having already formed two prior West Bengal governments (1967 and 1969), no consensus was ever reached on its long-term governance responsibilities. Additionally, post-1977, there was an overt sense that the Left Front could not be long-lived. Emerging from the emergency period (1972-1977), many Left leaders assumed that the central (Congress) government will soon overrule state governments. The focus was therefore to use this short-term access to power to bolster its political goals. In the words of Jyoti Basu:

...neither did we...believe that we would form a government, nor did we imagine that once formed, our government could stay in power for so long...we were not certain about what such a regional government would achieve within the capitalist and bourgeoisie parliamentary system (Introduction to Sen, 2008)

Therefore, compared to the more politically attuned tasks of land reforms and panchayati-raj, industrial revival was hardly a priority in 1977. Initially, this attitude paid rich political dividends that compensated for the economic woes, the CPIM entrenching itself in the remotest corners of the state. However, the situation changed from mid-1980s, as having consolidated politically, activism around land reforms and panchayats ebbed significantly. At the same time, the prospect of being in power for long, or at least longer than initially expected, began to dawn on the CPIM (Mukherjee, 2007). This created a rather challenging situation: the party could potentially enjoy a longer stint in office, but had no ideological consensus on its long-term role; neither was it confident about combating the pitfalls of parliamentary participation if in power for long, thus hindering the prospects of PDR. Under pressure from such conflicting positions, the party started debating its long-term duties by mid-1980s, at the forefront of which were the issues of industrialisation and private capital, formally voiced (as early as) at the 12th Party Congress (1985). vii In fact, the NEP provided the regime with a way out from political stagnation, the economic reforms being 'godsend for the CPM to get out of the impasse it had landed itself in' (ibid.:3). 
Initially, the political longevity and revolutionary character trade-off debates were largely confined to the higher echelons of the party, but the Soviet disintegration was a jolt to the CPIM. The opening lines of the 14th Party Congress admits:

The international situation in the period after the 13th party congress has been a...difficult one...The reverses suffered by socialism in the Soviet Union...have altered the world balance of forces in favour of imperialism.... we failed to grasp their deep implications...[T] he subsequent developments...were quite unexpected. (CPIM, 1993)

This was a serious setback. The Soviet disintegration had dealt a blow to the party's theoretical edifice. The 14th Party Congress therefore attempted to re-evaluate the existing ideological discourse, adopting a resolution on 'Certain Ideological Issues' - one of the most significant in the party's history - admitting for the first time a fallacy in its understanding of capitalism. It stated:

In retrospect, it can be said that the general crisis of capitalism was simplistically understood. The historical inevitability of capitalism's collapse was advanced as a possibility round the corner. This was a serious error...[T] he socialist revolutions... affected neither the levels of productive forces already attained by capitalism nor its future potential. (ibid.:94-96)

This introduced a fundamental change in the party's ideological discourse. While a detailed critique is beyond this paper's purview, it is important to note the shift in the party's political line henceforth. Essentially, the debates leading up to the 14th Party Congress and the resolution on Certain Ideological Issues provided the CPIM with an ideological middle ground. Having admitted that a socialist revolution was not imminent and some means of co-existing with capitalism needed to be found, it was now possible to weave the logic of capitalist production into its operational principles. The government could be given license to promote a more industry-friendly attitude and concentrate on basic development duties without appearing to lose its ideological character, thus making it possible to acknowledge that, 'while continuing to advocate a change in some important aspects of this NEP, we must take [its] fullest advantage' (GoWB, 1994:6). 
However, when it came to justifying and promoting the rhetorical changes, the party took a step backwards. Almost immediately after adopting the 1994 statement, the CPIM high-command tried to water down the scale of changes. The $15^{\text {th }}$ Party Congress (1995) pointed out that discrimination by the central government had led to industrial stagnation and large-scale job losses, rapid industrialisation thus being the only way forward. In such a situation:

...it has become necessary to adjust the industrial policy in the state...[But] doing so does not mean giving up or compromising on our basic strategic goals...[T] he strong base...in West Bengal will be mobilised to strengthen the all India struggle against the economic policies of the Centre.

...[w]hile implementing [industrialisation] policies...care should be taken to see that our government...do not...justify the liberalisation policies...The government's policies should be in defence of the public sector... [and]... must clearly set out alternative policies ... the Left Front will continue to play a leading role in the nationwide resistance to liberalisation and privatisation (15th Party Congress of the CPIM, 1995:100-101).

On the whole, this is a rather confusing argument, mainly on three counts. First, though the party promises not to subscribe to 'liberalisation policies', the 1994 Statement had already declared that it would take 'full advantage' of those very policies. Second, neither the government nor the CPIM delivered any subsequent plan detailing how such alternative policies would be set ${ }^{\text {viii }}$. Third, promoting state intervention as a political priority would discourage private capital from coming to West Bengal which, even the Congress admitted, was a necessity. This statement is possibly the only formal explanation of the transition that the CPIM provided during the 1990s, attempting to maintain the political sanctity of a pro-labour alternative instead, labelling the changes as necessary 'adjustments' rather than a fundamental transition. Given such an attitude, it is not surprising that although the 1995 Party Congress ideologically approved the industrialisation agenda, the situation on the ground (investment and job creation) remained sluggish at best (tables 4, 5 and 6). While most observers ascribe the sluggishness to institutional ineffectiveness and infrastructural inadequacy (Chakravarty and Bose, 2013), it is important to understand that the challenges of a populist transition were completely novel for the CPIM. It could not fall back on its traditional 
rhetoric, nor could it ignore the potential for the state's economic growth. In effect, it was left grappling with the dual pressure of developing a new development strategy and dealing with the ongoing ideological modifications. The result was an initial impasse, or a period of political indecisiveness that spilled over into the realm of policy making. The party had to strike a balance between projecting its traditional class character whilst attempting a liberal policy makeover, with little idea of how to go about it. Saifuddin Choudhury (ex-MP and CPIM central committee member), described the situation as chaotic:

By mid-1990s, we had realised that the earlier ways were redundant, and we needed to change, but there was hardly any clarity about the process. It was a serious contradiction. They had to maintain the traditional slogan of capitalists being the class enemies, and yet find a justification for inviting them to the state. The only argument was that the present circumstances compelled them to depend on private capital, but they will continue their opposition in principle. But why would industrialists come to the state if this is the declared attitude? In effect, it was a complete chaotic situation... wanting to create a pro-industry facade, and yet remain a revolutionary party at the core. .x $^{\text {ix }}$

Mr. Chaudhury was part of a pro-reform CPIM faction who eventually left the party in 2000. His views are however echoed by other party loyalists as well. Debashish Chakrabarty, the editor of the party's Bengali daily, Ganashakti, observes:

Earlier, all rallies/demonstrations would mouth the slogan bamfront sarkar shangramer batiyaar (the Left Front is a weapon of struggle). We believed that a Left government would give a fillip to the Indian democratic movement. But this was an oversimplification. While our initial focus was on redistributive reforms, we soon realised that the government cannot sustain on the basis of those alone, and thus was not an instrument for class struggle. It could provide a helping hand, but we were not sure how. ${ }^{\mathrm{x}}$

Such a lack of clarity on ideological issues naturally spilled over into the policy realm. Withstanding the promotions of West Bengal as an attractive investment destination, no political leader was willing to be seen courting private capital, including Jyoti Basu and Somenath Chatterjee, whose appeal to investors would always be carefully coated with a preamble of the discrimination-by- 
centre rhetoric. A senior official from the Confederation of Indian Industry (CII) summarised the situation aptly:

Throughout the 1990s, the CPIM remained peculiarly schizophrenic. They wanted investment but didn't want to be seen promoting industries...bureaucrats were often asked to hold back and even act hard to get. It was a peculiar situation, pulling and pushing at cross purposes. ${ }^{\text {i }}$

There was, evidently, a duality in the government's approach to industrialisation, along with a sense of directionlessness as reflected in both Chaudhury and Chakrabarty's views. Taken together, these indicate that the party's revolutionary credentials had come to be doubted within the party itself, but they were unsure about either proclaiming or rejecting it.

\section{<insert Table 4> \\ $<$ insert Table 5> \\ $<$ insert Table 6>}

Looking at the dynamics among the major Left Front coalition partners, the CPI usually remains moderate on policy matters, while RSP and FB take a much more hard-line stance. Of the smaller parties, the RCPI usually sides with the RSP/FB. The DSP, WBSP, MFB and RBC hardly have a voice, and depend on the CPIM for survival. Given this distribution, the RSP and FB are usually more critical of the Left Front as steered by the dominant partners. Therefore, the following CPI statement, testifying how the CPIM alone had come to dominate the coalition was indeed surprising:

The Left Front meetings are highly irregular. The member parties are not even informed of the agenda, which prevents them from discussing matters amongst themselves...At the meetings, neither there are any discussions on policy matters nor is the government's performance evaluated. The coalition partners have to read about policy measures in newspapers. (CPI $22^{\text {nd }}$ West Bengal State Conference, 2005:39-40)

As might be expected, RSP and FB are more vocal in their criticism of the CPIM. There were two major areas of discontent: firstly, as the CPI also admits, the lack of regular discussion among the 
Front members and the CPIM enforcing their decision on the other parties. Manoj Bhattacharya, West Bengal state secretary of RSP, said:

CPM's attitude is reminiscent of a Stalinist dictatorship- not listening to or negotiating with anyone - but deciding and executing on their own. It's not just arrogance, but intransigence.

Secondly, there were many differences between the CPIM and other parties on the industrialisation policy, with the former being accused of deviating from a Left path. These differences emerged on issues related to the nature of capital entering the state, capital versus labour intensive industries, special economic zones, land acquisition, rehabilitation and compensation procedures, etc. Given the pace at which the CPIM tried to proceed, Manoj Bhattachrya observed further, sensitive issues such as land acquisition, rehabilitation, etc. were almost bulldozed over.

The theoretical rationalisation attempted by CPIM ideologues such as Nirupam Sen (see next section) was also refuted by coalition partners. Mihir Bain (West Bengal state secretary, RCPI) observed:

This theoretical justification comes out of a compulsion to stay in power and is devoid of any ideological grounds. The CPIM...has totally deviated from Leftism. They are operating according to pure self-interest. ${ }^{\text {iii }}$

Manoj Bhattacharya was particularly vocal about the CPIM's complete disorientation from Leftism.

They may justify themselves by citing China. But they have completely shifted from the idea of Leftism... The class alignment that all the Left parties had once built has gradually started to dissipate. We have tried our best, but the CPIM refuses to hear anything, anyone. .iv $^{2}$

The above discussion demonstrates the unevenness in pursuing neoliberal modes of government in populist regimes, standing contrary to the assumption that 'one of the main successes of neoliberalization has been to place these discussions practically 'off-limits' in mainstream political discourse' (Tickell and Peck, 2003:177). The neoliberal governmentality that the CPIM built 
through the 1990s and 2000, remained besotted with these ambiguities, further emphasising the unique challenges faced by a populist alliance operating at the juncture of contradictory economic and political objectives.

\subsection{Neoliberal Governmentality in West Bengal}

The notion of neoliberal governmentality, as conceptualised earlier, refines the study of state sovereignty usually perceived as a political singularity, the state being a machine that steamrolls across the political terrain, imposing a uniform state bureaucracy. However, in actual practice, 'sovereignty is manifested in multiple, often contradictory strategies that encounter diverse claims and contestations, and produce diverse and contingent outcomes' (Ong, 2006.:7). It is this new mode of political optimisation that Ong labels as small $n$ neoliberalism, reconfiguring relationships between governing and the governed. The state of affairs in West Bengal has been demonstrative of this in a rather intriguing way, once again germane in the ideological conundrums of a populist transition.

In order to assuage the interventionist character of the transition, a very specific and unique kind of neoliberal governmentality took shape in West Bengal during the 1990s, evident from a close reading of key party documents. For example, CPIM's 19th West Bengal State Congress (1998) clearly admitted that 'our aim is a developed, people-oriented and sensitive Left Front government', with no reference to its revolutionary ambitions, echoing a similar admission already made in the $15^{\text {th }}$ Party Congress (1995):

...it is up to the Left Front...to initiate steps to attract capital investment... This can be done only by allowing greater investment of private capital in various sectors. This is the basis on which the Left Front... has to adjust its policies (pp. 100).

These statements indicate a gradual transformation in the regime's political attitude towards private industrialisation, something that only strengthened in the next few years. In 2000, the CPIM 
leadership undertook the task of updating the party programme (the original version dated back to 1964), formulating a renewed discourse for 'an alternative socialist order' that would take its shifted priorities into consideration. This was finally formalised at the $18^{\text {th }}$ Party Congress (2005), where the following observation was made:

[A]n alternative socialist order has to be based on the revolutionary transformation of the existing order...This, in turn, needs an engagement...of the revolutionary forces with the existing world realities with the sole objective of changing the correlation of forces in favour of socialism (CPIM $18^{\text {th }}$ Party Congress, 2005:29; emphasis in original).

Whether the above formulation indicates a reformist trend is a separate debate, but the key point is that from the late 1990s, the CPIM became evidently engaged in a continuous effort to formulate a legitimising discourse to validate its move towards more elaborate governance duties to facilitate its pro-market transition. The sort of political optimisation the party strived for was to give its actions a socialist stance. This was finally completed in the $18^{\text {th }}$ Party Congress, by adopting the semi-paradoxical stance of engaging with the forces of neo-liberalism to strengthen the party's quest for socialism.

However, what is extremely interesting is the subversion of this stance by the West Bengal leadership, giving it an altogether different spin to justify the intensive industrialisation campaign. The $20^{\text {th }}$ West Bengal State Party Congress adopted the resolution 'Left Front Government and Our Tasks' (2002:77), clearly admitting:

The Left Front Government is trying to protect the working class via an alternative policy. This is not an alternative to capitalism. Under the present federal structure of our country, no such alternative can exist (translated and emphasis added).

This is in complete contrast to the central leadership's claim of a 'socialist alternative'. Nirupam Sen, one of the chief ideologues from the state party leadership (and also the erstwhile industry minister), wrote a series of articles under the title Bikalper Shondhane (In Search of an Alternative), which has become the key reference on ideological questions. Sen clearly admits that 'the 
alternative specified in the party programme, is not a socialist alternative' (2008:2; translated and emphasis added) and asserts emphatically:

West Bengal is not a socialist state. There has been no attempt to bring socialism in West Bengal. Even a People's Democratic Front has not been established here. The path of the state is a capitalist path (ibid.:192; translated).

The absolute contrast between the central leadership position and the interpretation of the West Bengal leadership is highly surprising. The question that obviously follows is: how could such a difference be allowed to endure, and more importantly, be explained to the rank and file of the party? The explanation provided was rather convoluted, giving an additional spin to the 'capitalist path'. Sen explains:

The weakest link in the bourgeoisie-landlord rule...is the link between capitalism and feudalism...The Left Front should weaken this link even further...and this is where our alternative is embedded...We know capitalism is an advanced stage than feudalism, but inferior to socialism...therefore we cannot avoid the intermediary stage in our quest for socialism (ibid.:4).

How can this link be weakened? Sen goes on to elaborate:

$[\mathrm{U}]$ nless we can reduce the number of people dependent on agriculture and make them dependent on industry, no development can take place. So we need to industrialise our state, and invite private capital...allow it to make profit, be competitive (ibid.:66).

Read in isolation, the above is a perfect neoliberal argument. However, when read together with the preceding quote, it assumes a different character. To put simply, Sen and other CPIM leaders (particularly Buddhadeb Bhattacharya, who succeeded Jyoti Basu as the Chief Minister in 2000) have been arguing since 2000 that it is only by expediting the capitalist forces that they can abolish the remnants of feudalism and prepare for a socialist transition. As per the Marxian stages of revolution, it is only through an intensification and dissipation of the inherent contradictions of a fully-fledged capitalist system can a society progress to socialism. Therefore, the government should intensify its efforts to industrialise West Bengal via private capital as the only recourse to an eventual socialist transition. 
These are rather contentious claims, drawing vehement criticisms from prominent Left ideologues about a theoretical crisis (Patnaik, 2009). But it is also here that the small $n$ neoliberalism is clearly evident: a search for a legitimising discourse to strike a balance between the regime's revolutionary credentials and governance compulsions. Sen himself admits:

Forming government in one state cannot have anything to do with socialism....[I]n West Bengal...there is absolutely no question of proposing an alternative to capitalism, the alternative development model...is essentially adopting a pro-people attitude while accepting and operating within a capitalist structure. ${ }^{\mathrm{xv}}$

Theoretical merits aside, it is hard to deny the ingenuity of this conceptual amalgamation, a calculative mechanism to facilitate the interventionist neoliberal order by creating a new arrangement of (acceptable) capital and knowledge. This is also symptomatic of neoliberalism as exception, as it articulates a constellation of mutually constitutive relationships that are not reducible to one or the other. Much of the subsequent criticism of the regime, as indicated in the introduction, has been its deviation from the 'Left' way. But the point that needs to be asserted is that there was a novel interaction between market-driven mechanisms and a specific type of situated political practices in West Bengal, the specific type of neoliberal governmentality taking shape around such reflexive techniques of political engineering.

\section{Conclusion: Producing Local Neoliberalism in West Bengal}

Let us recall the key question of this paper: how was a distinct form of local neoliberalism produced by the CPIM/Left Front in West Bengal? The paper argues that the traditional critique of the industrialisation strategy and institutional effectiveness is only a part of the story, and the recent 'dilution of Leftism' rhetoric renders an overt moralistic sense to it, relegating much of the nuanced historical complexities to the sidelines ${ }^{\mathrm{xvi}}$. The effort in this paper has been to bring much of those rarely discussed complexities to the forefront, and to argue that the transition engineered by the 
CPIM/Left Front was demonstrative of a certain proactive reconfiguration of political rationalities, that on one hand reflects similar modes of intervention elsewhere in the global South, while presents a rather distinct mutation of neoliberal governmentality due to its populist character on the other. Its salient features were: the industrial policy transition, the shifts in the party's attitude towards private capital, the subsequent institutional initiatives, de-linking governance from politics, the rhetorical shifts from revolution to governance, and the ideological conundrums and reconciliation attempts. Such a reassessment of the West Bengal story also adds to the wider literature on Indian liberalisation by demonstrating its plurality and significant regional variations, i.e. the crucial determinant of local political logic (Jenkins, 1999), in addition to the fact that the Left bastion in West Bengal was often perceived as the final stumbling block for the reforms to take root in the country (Corbridge, Harriss, and Jeffrey, 2013). Finally, such a characterisation of the regime also has a lot to offer in developing an understanding of the contemporary political history of the Indian Left, as it finds itself increasingly marginalised both in West Bengal and nationally.

In a broader sense, the analytical notion of local neoliberalism deconstructs the unitary logic of the market by bringing its variegated bottom-up political actions and political incorporation under scrutiny. This also stands in contrast to the two conventional anthropological schools of thought, a Northern 'culture of neoliberalism', and 'neoliberal states' centralising capital and monopoly power at the global level (Ong, 2006). David Harvey, for example, invokes an ideal-type 'neoliberal state', thus unwittingly presenting the state as an entity of singularity. But as Ong further argues, 'the dynamic and novel combinations of neoliberal interventions...challenge typological approaches based on...nation states. Rather than taking neoliberalism as a tidal wave of marketdriven phenomena... we could... break neoliberalism down into various technologies: the kind of political exceptions... and subjectifying techniques that deviate from the established norm' (ibid.:12). The populist transition variant further problematises such formations, even Harvey (2004) referring to China as a 'strange case' because of the analytical difficulty of reconciling a 
socialist formation with feverish capitalist activity. West Bengal is another such strange case, and it is only by studying the internal ideological contradictions and tactical shifts can one understand its true nature.

The distinct shape of local neoliberalism in West Bengal demonstrates certain proactive forms of statecraft, what Tickell and Peck describe as a new 'regulatory unsettlement... with the effect of consolidating a series of neoliberal movements in political rationalities, policy conventions and modes of intervention' (2003:177). It is also demonstrative of the increasingly activist strategies employed by the interventionist neoliberal order to continuously manage and facilitate markets in response to the emergent contradictions, thus pointing to the internal dynamics of transformation within the attempts to create geographically distinctive forms of neoliberal governmentality. In studying such dynamics, both exogenous and endogenous factors can provide varying explanations (Katz \& Mair, 1995; Levitsky, 2001). While exogenous environmental factors can 'set the stage' by describing whether political space exists for parties to attempt to move in the political spectrum (Samuels, 2004:1001), one also needs to explore parties' internal dynamics to obtain a complete explanation of strategic changes. In this sense, further work on this research can blend itself into broader instances of other forms of local neoliberalisms elsewhere. For example, the gradual transformation of the Workers' Party (PT) in Brazil from 'socialism to social democracy' (ibid.), the pro-market turn of the Chinese Communist Party, the doi moi programme in Vietnam, and so forth. Thematic parallels can also be found in Thatcherism in England, or more recently, in the way the Labour Party seeped into the ideas of New Labour.

To conclude, the reconceptualisation of the populist transition in West Bengal as an interventionist neoliberal governmentality, producing a specific variant of local neoliberalism, can be seen as poststructural attempt to deconstruct the neoliberalism behemoth into a series of mobile calculative techniques of governing. In this sense, the story takes forward what Ong (2006) describes as the process of decontextualising the grand neoliberal order, and recontextualising in constellations of 
mutually constitutive, contingent, and most importantly localised relationships, operating within an interlocked space that is both the site of the problem and its resolution.

\section{References}

Amin, A. (1997). 'Placing Globalisation', Theory, Culture and Society (14), pp. 123-137.

Bandopadhyay, D. (2006) 'Demise of an Ideology', Mainstream, 44(19), pp. 7-8.

Banerjee, S. (2008) 'A Political Cul-de-sac: CPI(M)'s Tragic Denouement', Economic and Political Weekly, 43(42), pp. 12-15.

Bardhan, P., Mitra, S. Mookherjee, D. and Nath, A. (2012). 'Why the Left Front Lost West Bengal', available at people.bu.edu/dilipm/wkpap/wbpolchNov12.pdf

Bauer, P.T. (1981). Equality, the Third World and Economic Delusion. London: Weidenfeld and Nicolson.

Bhattacharyya, D. (2016). Government as Practice: Democratic Left in a Transforming India. New Delhi: Cambridge University Press.

. (2010). "Left in the Lurch: The Demise of the World's Longest Elected Regime",

Economic and Political Weekly, XLV(3), pp. 51-59. 
(2009). "Of Control and Factions: “The Changing 'Party-Society' in Rural West Bengal", Economic and Political Weekly, 44(9), pp. 59-69.

(2004). "West Bengal Permanent Incumbency and Political Stability", Economic and Political Weekly 39(51), pp. 5477-83.

Block, F. (1994). 'The Roles of the State in the Economy', in N.J. Smelser and R. Swedberg (eds), The Handbook of Economic Sociology, Princeton, NJ: Princeton University Press, pp. 691-710.

Bose, P. (2013). Left in West Bengal: Facing ideological crisis. Retrieved 5 September 2013, from http://www.pragoti.in/node/4991

Brenner, N., and Theodore, N. (2002a). Preface: 'From the 'New Localism' to the Spaces of Neoliberalism', Antipode 34(3), pp. 341-347.

(2002b). 'Cities and Geographies of Actually Existing Neoliberalism', Antipode 34(3), pp. 349-379.

Bret, E.A (2008). "State Failure and Success in Zimbabwe and Uganda: The Logic of Political Decay and Reconstruction in Africa", Journal of Development Studies, 44(3).

Burgess, K. (2004). Parties and Unions in the New Global Economy. Pittsburg, Pa: University of Pittsburgh Press.

Burgess, K., and Levitsky, S. (2003). "Explaining Populist Party Adaptation in Latin America: Environmental and Organizational Determinants of Party Change in Argentina, Mexico, Peru and Venezuela”. Comparative Political Studies, 36 (8), pp. 881-911. 
Cerny, P.G. (1990). The Changing Architecture of Politics: Structure, Agency and the Future of the State, London: Sage.

Chakravarty, D., and I. Bose. (2013). 'Industrialising West Bengal: The Case of Institutional Stickiness', in Kunal Sen (ed.), State Business Relations and Economic Development in Africa and India, London: Routledge, pp. 181-97.

Chatterjee, J., and Basu, S. (2009). West Bengal: Mandate for change. Economic and Political Weekly, 44(39), pp. 152-156.

Chibber, V. (2003). Locked in Place: State Building and Late Industrialization in India. Princeton, NJ: Princeton University Press.

CPI (2005). Political Report of the 22nd CPI West Bengal State Congress.

CPIM (1993). Documents of the 14th Party Congress of the CPIM

: (1995): Documents of the 15th Party Congress of the CPIM.

: (2005) Documents of the 18th Congress of the CPIM.

: (1998) Documents of the 19th West Bengal State Congress of the CPIM.

-: (2002) Documents of the 20th West Bengal State Congress of the CPIM.

: (2005) Documents of the 21st West Bengal State Congress of the CPIM.

Corbridge, S., Harriss, J., and Jeffrey, C. (2013). India Today: Economy, Politics and Society, Cambridge: Polity. 
Das, R. (2018). Neoliberalism and the Transforming Indian Left: A Contradictory Manifesto. Oxford: Routledge.

Das, R., and Mahmood, Z. (2015). 'Contradictions, Negotiations and Reform: The Story of Left Policy Transition in West Bengal', Journal of South Asian Development, 10(2), pp. 199-229.

Dasgupta, S. (1998). "West Bengal and Industry: A Regional Perspective", Economic and Political Weekly, Vol. XXXIII(47-48), pp. 3049-60.

Dicken, P. (1997). ‘Transnational Corporations and Nation-States', International Social Science Journal 49, pp. 77-90.

. (1998). 'Globalization: An Economic-Geographical Perspective', in W.E. Halal and K.R. Taylor (eds)Twenty-First Century Economics, New York: St. Martin’s Press, pp. 31-51.

Dicken, P., Peck, J., and Tickell, A. (1997). 'Unpacking the Global', in R. Lee and J. Wills (eds), Geographies of Economies, London: Arnold, pp. 158-66.

Dieleman, M., and W. Sachs. (2008). 'Coevolution of Institutions and Corporations in Emerging Economies: How the Salim Group Morphed into an Institution of Suharto's Crony Regime', Journal of Management Studies, 45(7), pp. 1274-1300.

Ghosh, B., and P. De. (2005). "Investigating the linkage between infrastructure and regional development in India: era of planning to globalisation", Journal of Asian Economics (15).

Gibson, E. (1997). “The Populist Road to Market Reform: Policy and Electoral coalitions in Mexico and Argentina”, World Politics, 49(3), pp. 339-370. 
Government of India (GOI): Summary Results of Annual Survey of Industries, various years, published by the Central Statistical Organisation.

Government of West Bengal (GoWB) (1978): Statement on Industrial Policy.

-: (1994) Policy Statement on Industrial Development,

-: (1991) The Left Alternative Approach.

: Economic Reviews (various years)

Gohain, H. (2011) "Decline of the Left: A Critical Comment", Economic and Political Weekly, Vol. XLVI (38), 17th September.

Grindle, M. S. and Thomas, J. W. (1991). Public Choice and Policy Change: The Political Economy of Reform in Developing Countries. The Johns Hopkins University Press, Baltimore.

Haggard, S., and Kauffman, R. (1992). "Institutions and Economic Adjustment". In Stephen Haggard and Robert Kauffman (eds.) The Politics of Economic Adjustment. Princeton, NJ: Princeton University Press.

Haggard, S., and Webb. S. (eds). (1994). Voting for Reform: Democracy, Political Liberalization, and Economic Adjustment. New York: Oxford University Press/The World Bank.

Harvey, D. (2004). Neoliberalism and the Restoration of Class Power, unpublished manuscript, CUNY Graduate Centre, available at https://gsnas.files.wordpress.com/2007/10/harvey080604.pdf 
Jenkins, R. (1999). Democratic politics and economic reforms in India. Cambridge: Cambridge University Press.

Khasnabis, R. (2008). "The Economy of West Bengal". Economic and Political Weekly. 27 December.

Katz, R., \& Mair, P. (1995). "Changing Models of Party Organization and Party Democracy: The Emergence of the Cartel Party. Party Politics, 1(1), pp. 5-28.

Kohli, A. (1987). The State and Poverty in India: The Politics of Reform. Cambridge University Press. Krueger, A. (1992). Economic Policy Reform in Developing Countries. MA: Blackwell Publishers.

Lal, D. (1983). The Poverty of Development Economics. London: Hobart Paperbacks.

Larner, W. (2000). Theorising Neoliberalism: Policy, Ideology, Governmentality', Studies in Political Economy (63), pp. 5-26.

Lavigne, M. (1999). The Economics of Transition: From Socialist Economy to Market Economy. London: Macmillan.

Levitsky, S. (2001). Organization and labor-based party adaptation: The transformation of Argentine Peronism in comparative perspective. World Politics, 54(1), pp. 27-56.

Little, I.M.D. (1982). Economic Development: Theory, Policy, and International Relations, New York: Basic Books. 
Mallick, R. (1993). Development Policy of a Communist Government. Cambridge: Cambridge University Press.

Moore, M. (1997). "Leading the Left to the Right: Populist coalitions and economic reform". World Development, 25(7), pp. 1009-1028.

Mukherjee, S. (2007). 'The Use and Abuse of Democracy in West Bengal', Economic and Political Weekly, Vol. XLII(44), pp. 101-108.

Murillo, M.V. (2001). Labor Unions, Partisan Coalitions, and Market Reforms in Latin America. Cambridge: Cambridge University Press.

Nelson, J. M. (1990). Economic Crisis and Policy Choice: The Politics of Adjustment in the Third World. Princeton, NJ: Princeton University Press.

Nielsen, K.B. (2018). Land Dispossession and Everyday Politics in Rural Eastern India, NY: Anthem.

Nossiter, T.J. (1988). Marxist State Governments in India. London: Pinter Publications.

Offe, C. (1984). Contradictions of the Welfare State, London: Hutchinson.

O’Neill, P.M. (1996). 'In What Sense a Region's Problem? The Place of Redistribution in Australia's Internationalisation Strategy', Regional Studies 30, pp. 401-12. (1997). 'Bringing the Qualitative State into Economic Geography', in R. Lee and J. Wills (eds), Geographies of Economies, London: Arnold, pp. 290-301. 
Ong, A. (2006). Neoliberalism as Exception, London: Duke University Press.

Patnaik, P. (2009). "Reflections on the Left", Economic and Political Weekly, $11^{\text {th }}$ July.

Pederson, J.D. (2001). “India's Industrial Dilemmas in West Bengal”, Asian Survey, 41(4). pp. 646668.

Peck, J., and Tickell, A. (2002). 'Neoliberalizing Space', Antipode 34(3), pp. 380-404.

Polanyi, K. (1944). The Great Transformation. Boston: Beacon Press.

Pooley, S. (1991). 'The State Rules, OK? The cOntinuing Political Economy of Nation-States', Capital and Class 43, pp. 65-82.

RayChaudhuri, A., and G.K. Basu. (2007). "The Decline and Recent Resurgence of the Manufacturing Sector of West Bengal: Implications for Pro-Poor Growth from an Institutional Point of View". IPPG Discussion Papers Series 10. School of Environment \& Development, University of Manchester.

Rodrik, D. (1998). "Promises, Promises: Credible Policy Reform via Signalling”, in Frederico Sturzenegger and Mariano Tommasi (eds), The Policy Economy of Reform, Cambridge, Massachusetts: The MIT Press.

Rogaly, B. (1994). 'Rural Labour Arrangements in West Bengal, India', PhD Dissertation, St. Anthony's College, University of Oxford. 
Rogaly, B., Harris-White, B., and Bose, S. (1995). Sonar Bangla? Agricultural Growth and Agrarian Change in West Bengal and Bangladesh. New Delhi: Sage Publications.

Roy, A. (2002). City Requiem, Calcutta: Gender and the Politics of Poverty. Minneapolis: University of Minnesota Press.

(2004). “The Gentleman's City: Urban Informality in the Calcutta of New Communism". in Roy, A., and Alsayyad, N (eds) Urban Informality: Transnational Perspectives from the Middle East, Latin America, and South Asia, 2004. Lanham, Maryland: Lexington Books.

Ruud, A.E. (1999). 'Embedded Bengal? The Case for Politics'. Forum for Development Studies (2).

Sachs, J.D., Bajpai, N., \& Ramiah, A. (2002). Understanding regional economic growth in India. Centre for International Development Working Paper No. 88, Harvard University.

Sáez.L. (2002). Federalism Without a Centre: The Impact of Political and Economic Reform on India's Federal System, New Delhi: Sage Publications.

Samuels, D. (2004). "From Socialism to Social Democracy: Party Organization and the Transformation of the Workers' Party in Brazil", Comparative Political Studies, 37(9), November, pp. 999-1024.

Sarkar, A. (2006). "Political Economy of West Bengal: A Puzzle and a Hypothesis". Economic and Political Week.ly, 41(4), pp. 341-48.

(2007). 'Development and Displacement: The Story of Land Acquisition in West Bengal', Economic and Political Weekly, 42(16), pp. 1435-42. 
Sarkar, T., and Chowdhury, S. (2009). “The Meaning of Nandigram: Corporate Land Invasion, People's Power, and the Left in India", Focaal-European Journal of Anthropology, 54, pp. 73-88.

Sen, N. (2008). Bikalper Shandhane (In Search of an Alternative). Calcutta: National Book Agency.

Shankar, K. (2011). "On the Left in Decline", Economic and Political Weekly, XLVI(47), 19th November.

Sinha, A. (2004). "Ideas, Interests and Institutions in Policy Change: A Comparison of West Bengal and Gujarat", in Rob Jenkins (ed), Regional Reflections: Comparing Politics Across India's States: Case Studies of Democracy in Practice. Oxford University Press.

-. (2005) The Regional Roots of Development Politics in India: A Divided Leviathan. Bloomington: Indiana University Press.

Steur, L, and Das, R. (2009) 'What's Left? Land Expropriation, Socialist “Modernizers”, and Peasant Resistance in Asia', Focaal - European Journal of Anthropology, 54, pp. 67-72.

Tickell, A., and Peck, J. (2003). 'Making Global Rules: Globalization or Neoliberalization?’ in J. Peck and H. Yeung (eds) Remaking the Global Economy: Economic Geographical Perspectives, London: Sage, pp. 163-181.

Yeung, H.W., and Peck, J. (2003). 'Making Global Connections: A Geographer's Perspective', in in J. Peck and H. Yeung (eds) Remaking the Global Economy: Economic Geographical Perspectives, London: Sage, pp. 3-23. 
i See, for example, Bauer (1981), Little (1982), Krueger (1992), Lal (1983), and Nelson (1990).

ii The term 'state' in India indicates regional province, and not the entire nation.

iii A nine party coalition, with the CPIM being the dominant partner. Other parties were: All India Forward Block

(FB), Communist Party of India (CPI), Revolutionary Socialist Party (RSP), Marxist Forward Block (MFB),

Revolutionary Bengali Congress (RBC), Democratic Socialist Party (DSP), Revolutionary Communist Party of India (RCPI) and West Bengal Socialist Party (WBSP).

iv Between the 2006 and 2011 elections, the CPIM's vote share reduced from 176 to 40.

${ }^{\vee}$ For example, an incentive scheme for new as well as expansion of existing units,; tax concessions announced in the 1993-94 state budget; streamlined and simplified sales tax laws and procedures, etc.

${ }^{v i} \mathrm{He}$ later went on to become the parliamentary Speaker, but was eventually evicted from the party in 2010.

vii It should be noted that from the mid-1980s, the Left Front started to gradually engage with private capital.

Two of the earliest and most publicised joint ventures were an electronics complex involving Philips and WBIDC, and a petrochemicals hub at the port-town Haldia.

viii This is different from the wider discourse of a 'Left alternative' as discussed earlier, as the attempt is to evaluate alternatives to each and every industrial initiative.

ix Source: Interview with author; $31^{\text {st }}$ July 2009, New Delhi.

x Source: Interview with author; $22^{\text {nd }}$ December 2009, Calcutta.

xi Source: Interview with author (anonymity requested); $30^{\text {th }}$ June 2009 , Calcutta

xii Source: Interview with author; $15^{\text {th }}$ June 2009 , Calcutta.

xiii Source: Interview with author; $20^{\text {th }}$ June 2009, Calcutta.

xiv Source: Interview with author; $15^{\text {th }}$ June 2009, Calcutta.

${ }^{x v}$ Source: Interview with author; $22^{\text {nd }}$ September 2009, Calcutta.

xvi This is also why the paper doesn't venture into the electoral/political crisis that emerged after the SingurNandigram incidents, leading to the regime's eventual capitulation in 2011 . The purpose here is to bring the 
oft-ignored historical nuances in its management of the transition and production of local neoliberalism, a process that had started in the 1980s. 